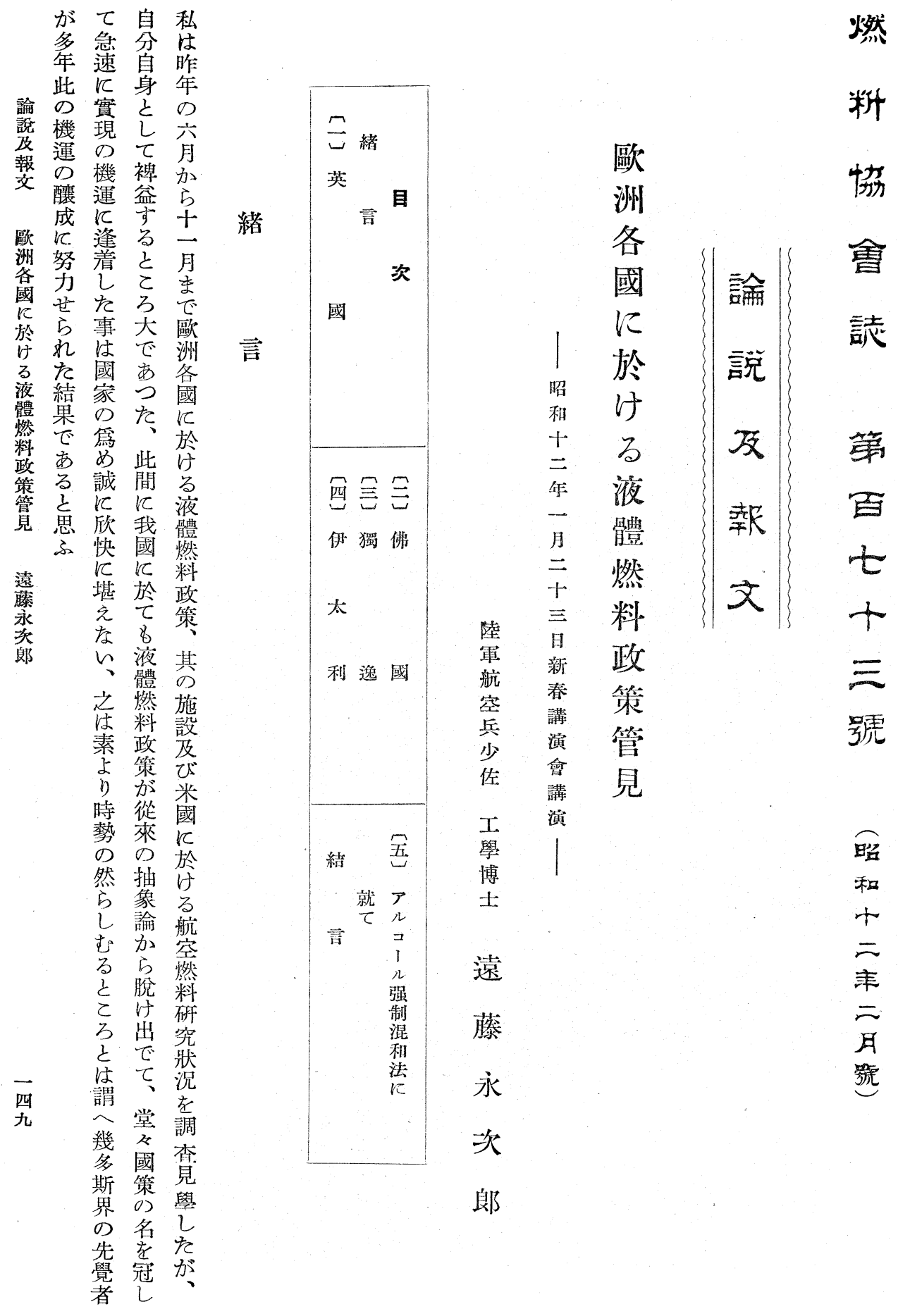


月二年二十和昭

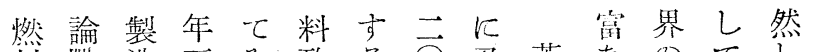

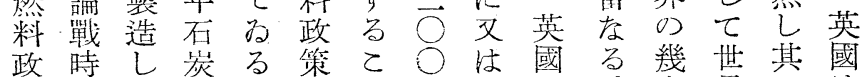

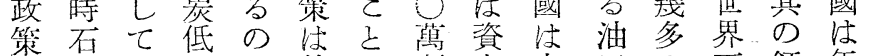
之油为溫み將络噸本本田の石領年 香自乾な來國以的土先油土額 著給、餾

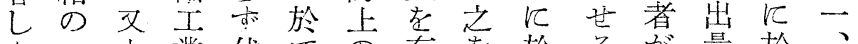
く一不業代て市有老於る染量於

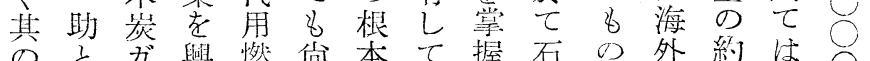

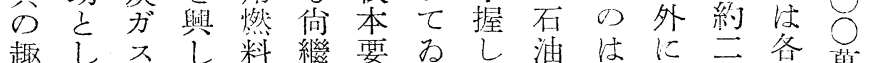

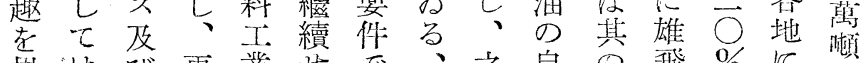

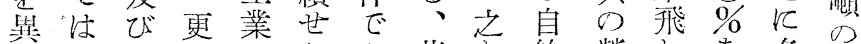

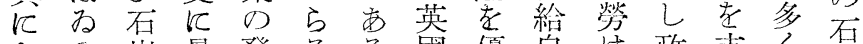

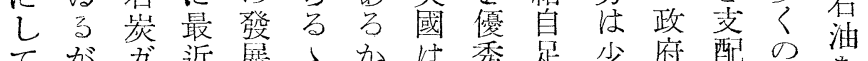

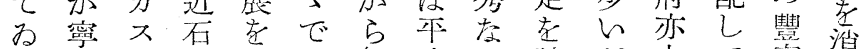

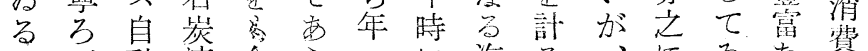
石動液企ら一飞海る、にる㔔 炭車化圖引、门於雷乙英多る、泄

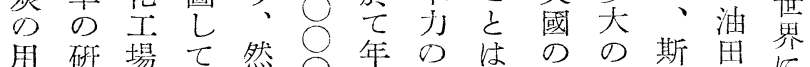

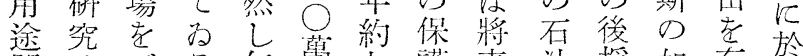
開はどる乍雷七護來油援如有於

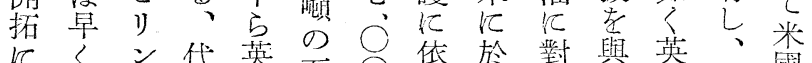

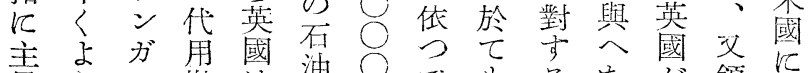

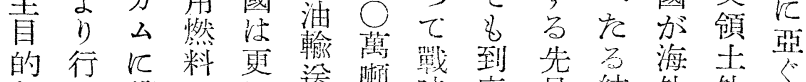

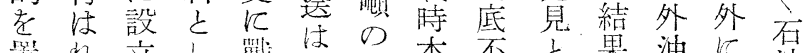

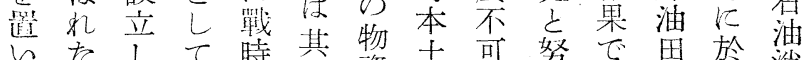
てた して石は石基資土能努で田於消

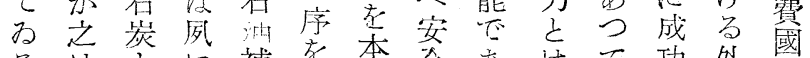

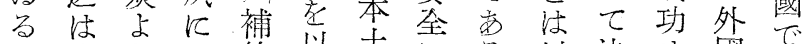

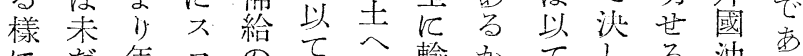

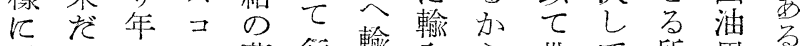

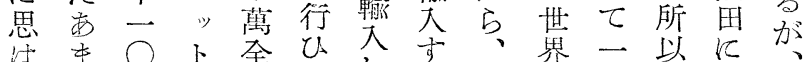

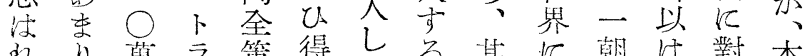

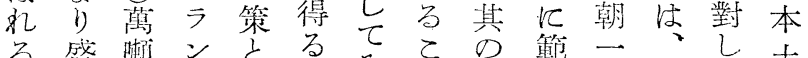
る、盛赖 ゙ 從で低にてでる在油垂の艮名注 つ以溫於本蓋で眼政れ女皆末 て 逸、儿岩に當てし海の存号滴

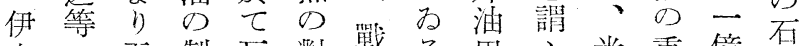
态代葛造額策時名思心米重億莯 等用顿にの西此, 從開きの性千多

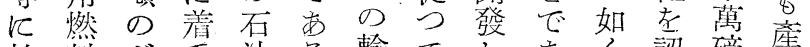

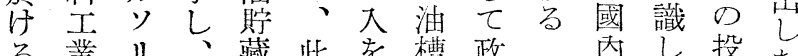

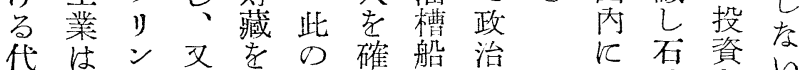
用勿を近し然保は的豐油考方

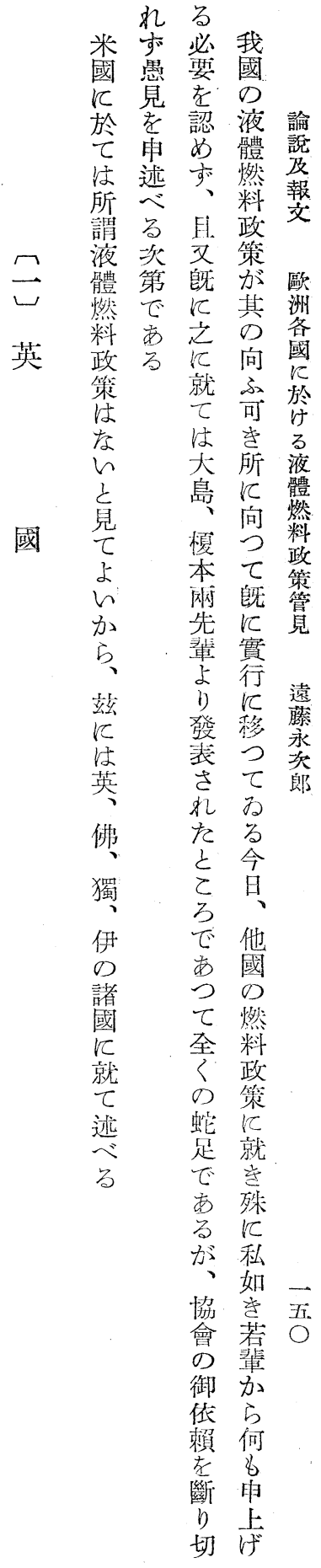


鼻の 代率 年め゙ 擔快佛䒠は年石卡佛 せ石國備我間油程國 し油の就國に業のは 諭業液中以二法苦咸 說了法體航上 $\bigcirc$ は杯に 報在液料勢貲萬名賞界 文る 體 政丹少噸なる大 、燃策のでを \& て 戰

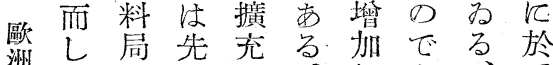

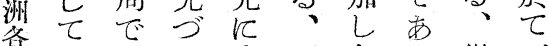
國一市一專而今名從石 少る九念し偷、つ油

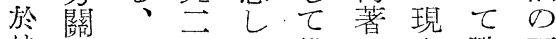
け稅其五て佛し在戰不 液政の年为國的佛後足 體策石にる、增國液に 燃に油發、諸加の體依 料依業希從强率石燃つ 政つ法世つ國走油料て 策てのらてと示渻對戰 管石目れ現隣し費策局 油的を代接て量にに

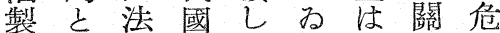
遠品高律防加る 年し 機

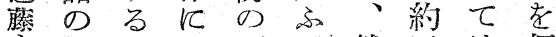
永輸之依原当然五は招 炊とつ動に方 $\bigcirc$ 非來 郎をるて力近に○常し 防は實厄來一萑のフ 遏石施 あ㰧方噸關劣 し油のる洲石で心シ 原の緒 液政油あ之二 油輸、體局のつ努元 の人就然の產て 万師 輸業々料不出、cを 大支をの安は一学し にび\& 戰著僅九傾て 依製の時し加三注口 つ油で對くに○し石

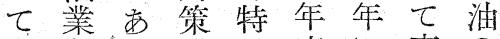
國をつはに崖に來の 內認て佛獨八杖六二 製可、國逸蓠約の滴 油制同のの噸三だは 業と法國軍に○市 一老し律防備過○つの

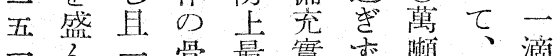

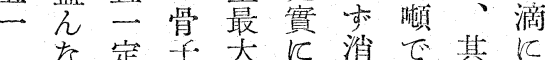
ら 量之の刺費あの值 己の孝間戟につ液す

め貯一題せ 對を體し た油ててら市文然京 の義わ需当の料叫 で務るるて產が局ば あを近油六及し

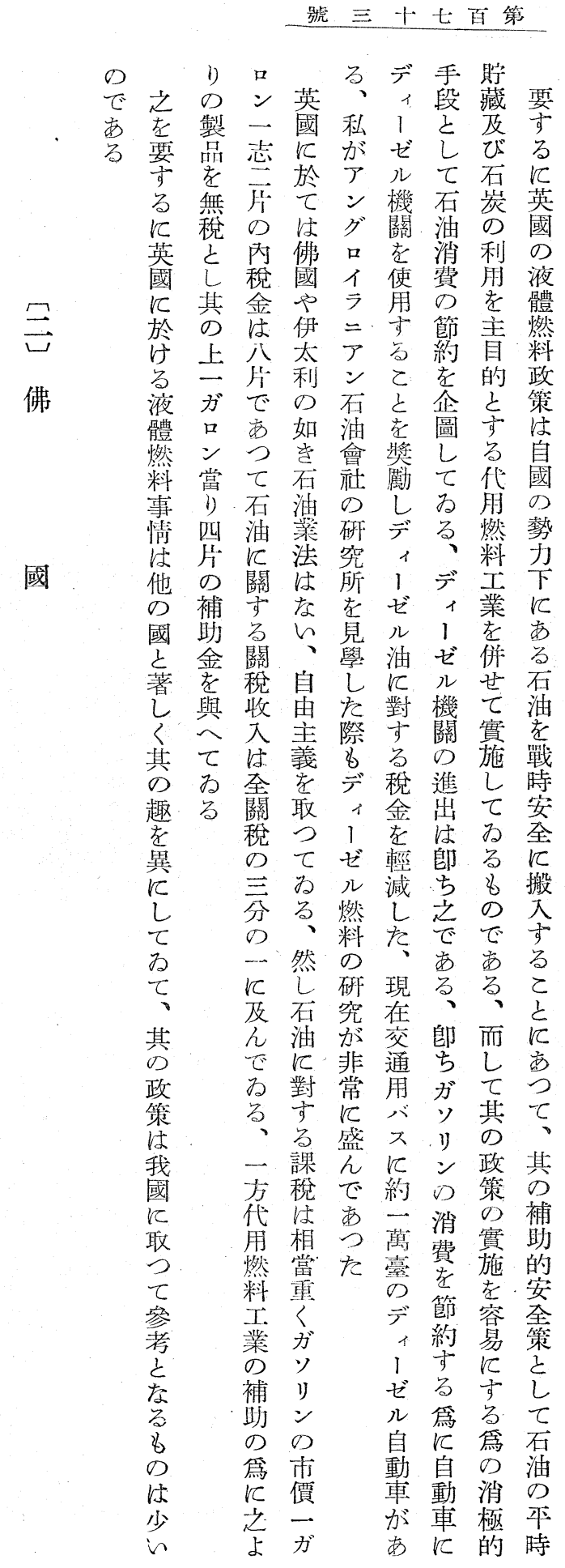


月二年二十和昭

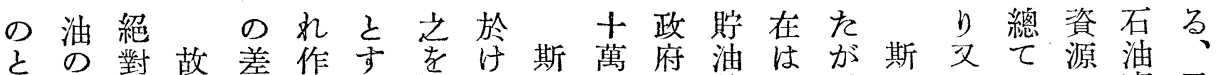

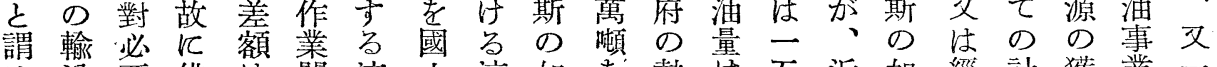
は送要佛は閉液土液如を熱度五近如經計獲業一 なを罗之或之始體外體く探热王年き濟畫得及方諞 け確しは存の燃に燃佛油を

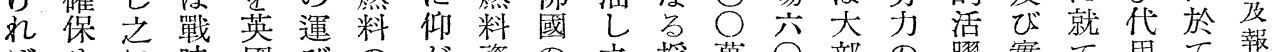
ばせに時國びのが凟の之援萬○部の躍實て用て㪈

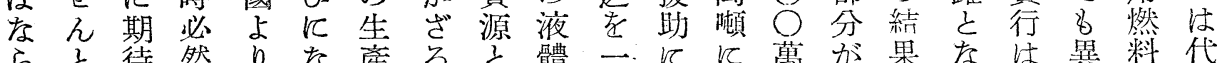

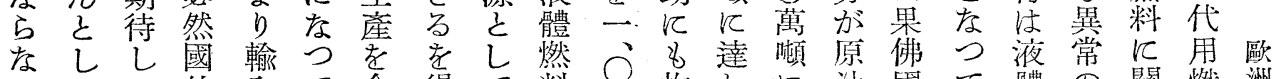

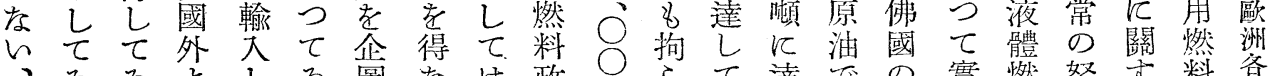

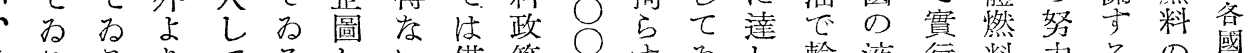

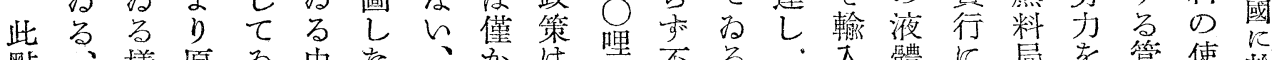

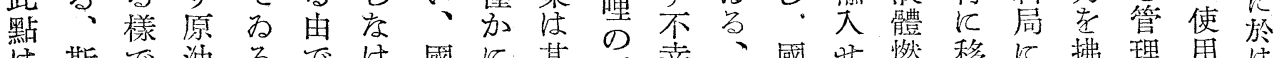
は斯で油るでけ國に其只幸、國吨燃移に拂理用け

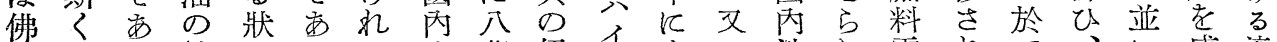

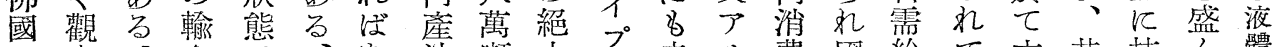
の察、大王、油噸大 プ未ル費國給て立其技ん䯖

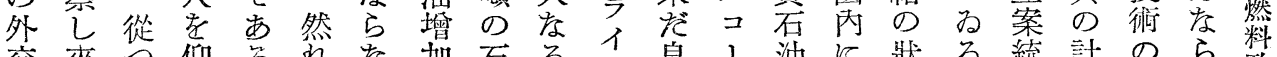

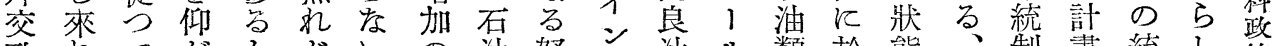

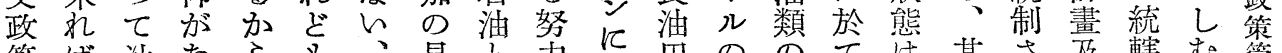

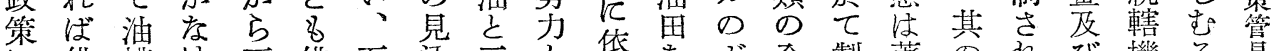

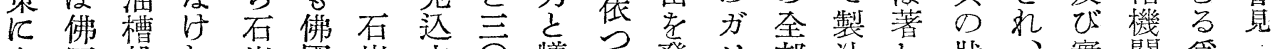

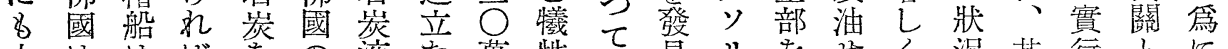

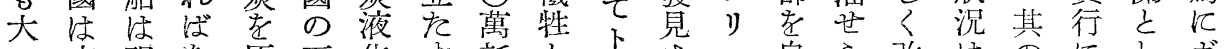

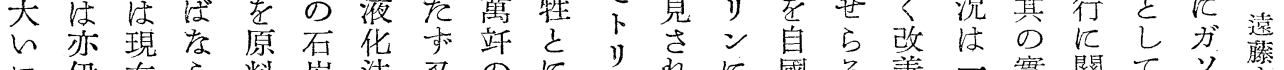

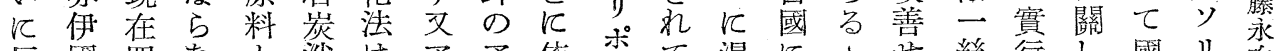

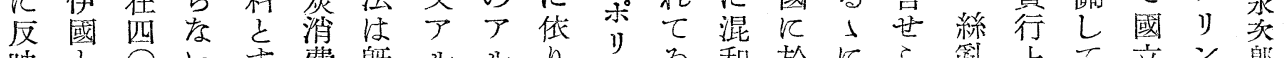

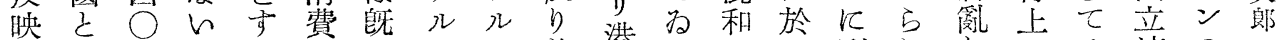

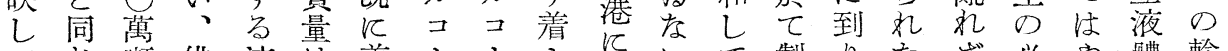

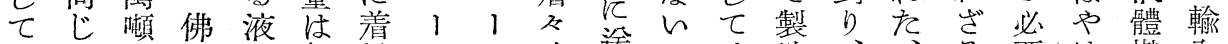

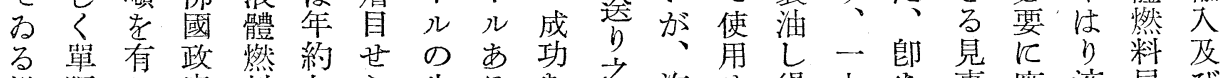
樣獨し府料七ら生る孝海せ得九号事應液局び

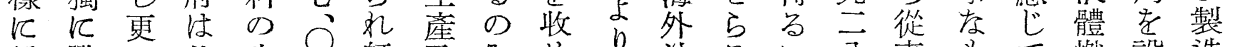
思戰に此生皖及みめ自油るに公來るて然設造

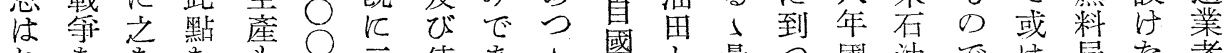

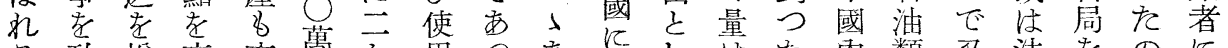

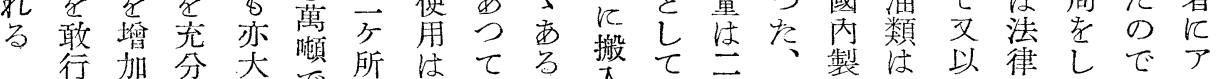

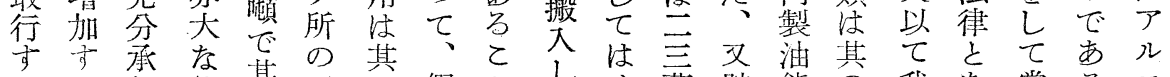

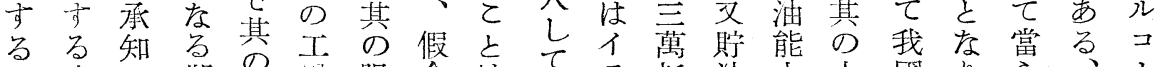

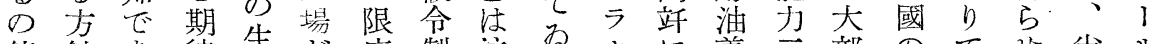

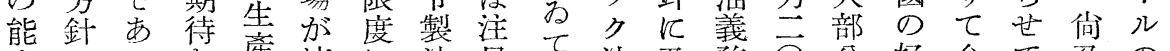

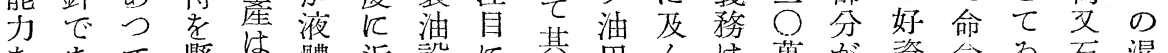

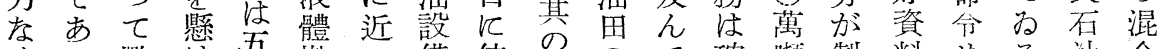

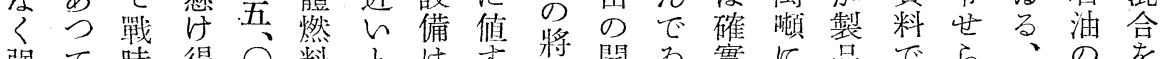

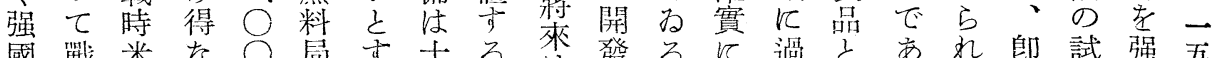

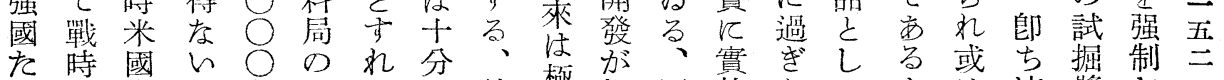

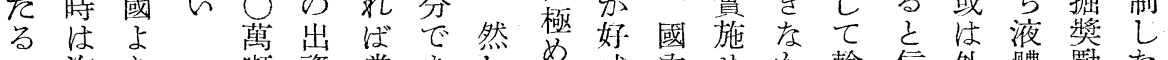

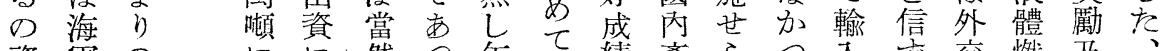
資軍の 飞然つ乍有績產らつ大弯交燃及、 格力原滿て石てら有望油れたせる的料び而 を油夲建炭\&本琶現の現\&方手江海し

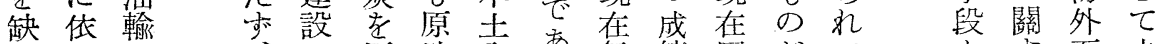

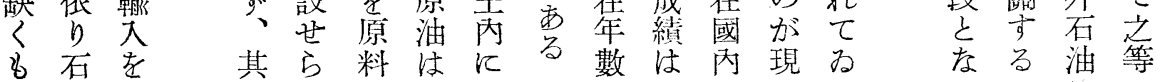


コ後用に夕六炭を基

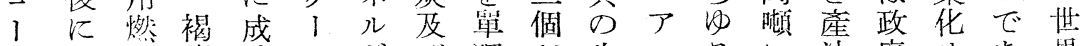
儿於料炭功儿ギび獨が生儿るに油府せ界

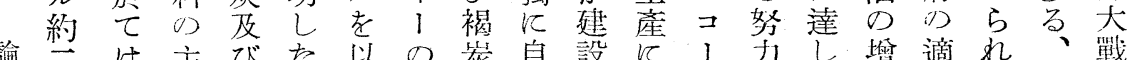

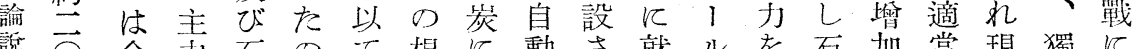

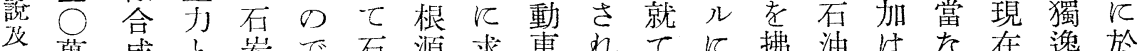

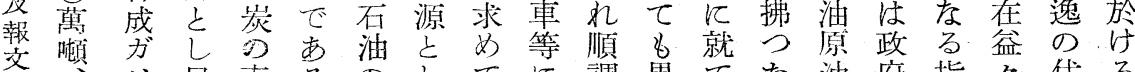

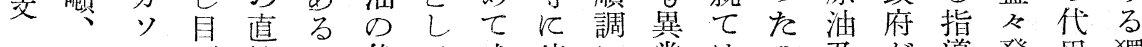

石リ下接代文成使に常は心支が導發用獨

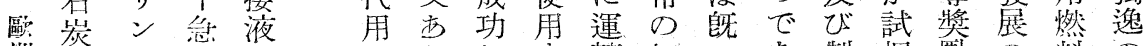

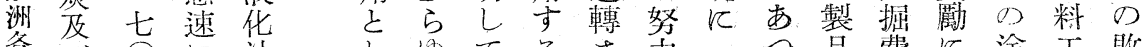

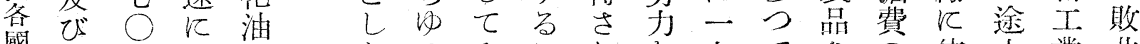

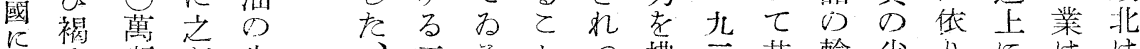

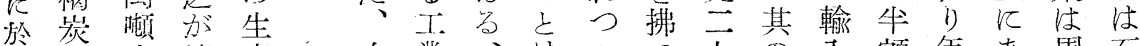
け液生撗產、次業、は小无少入額年あ周石 る化產張は注の獨不あた年主はを產る知油 液油 ○現褐基逸利る結以な依補約、の不 體約豫努在炭礎は岕、果來る然助四元如足 燃五 定め年 の c 發 政 ○でて 産水し見る儿近律のして 萬獨世依 策萬 あわ四 素て 埋 か

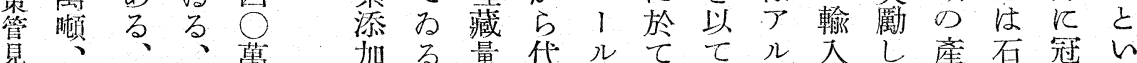

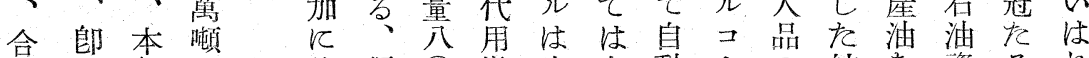

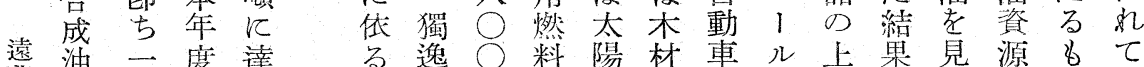

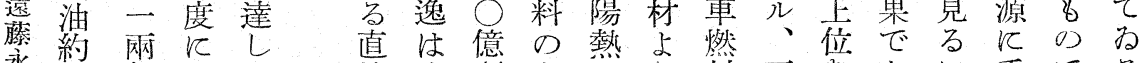

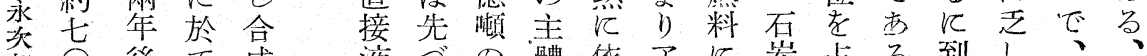
郎 $\bigcirc$ 後て 成液づの體依アに炭与占到し、

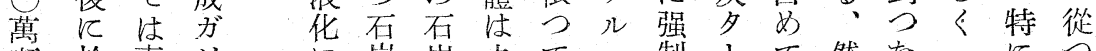
噸於直り 炭炭方て

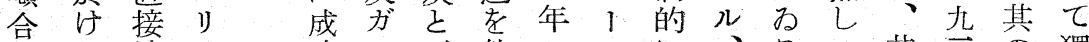
䚵学液 $ン$ 功

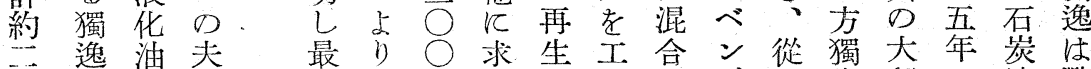

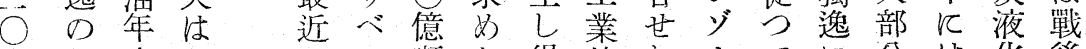

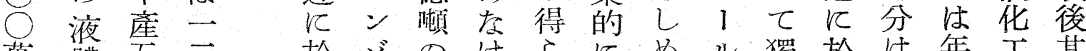
萬體五二於 シ の け ら

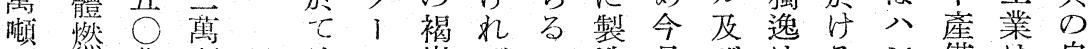

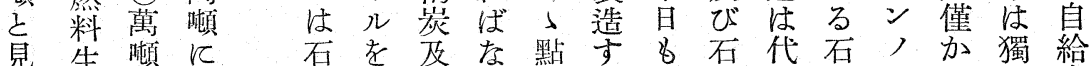

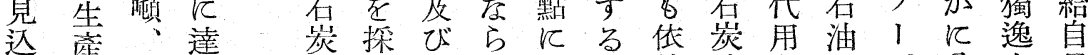
み量合し の取留な於こ然掖然のバ八人足

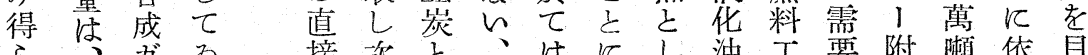

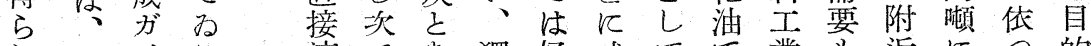
れ國ソ多液で獨好成てで業8 近につ的

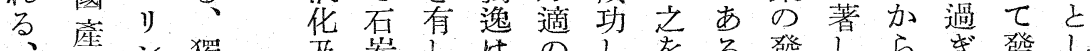

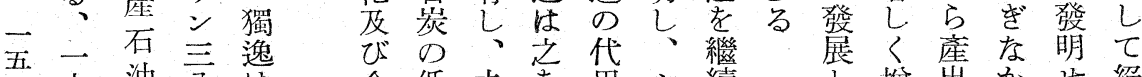

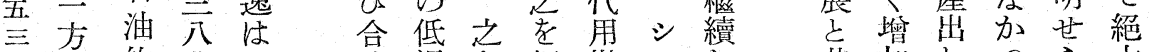
獨約萬此

逸 五 噸 D

の

石萬更法

消 次

費 ア 网 て

成溫を 埋 燃 $\equiv$ ᄂ

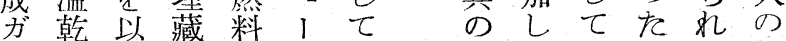
ソ餾て 量でラわ使て わ が獨努 リにあ䜾あ、角現名今逸力 ン依ら富る法、在、日にを のるゆながの而對五斯に於拂

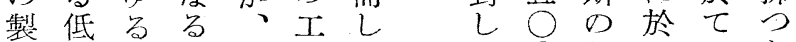

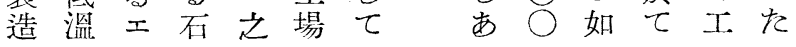




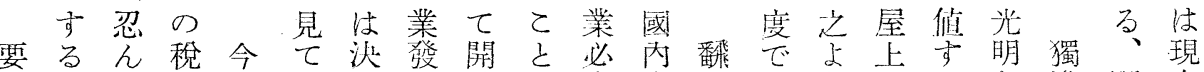

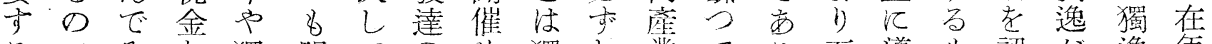

るでる老獨明ての獨し業て る石導为認䜑逸年

にある課逸加其理ら逸\&獨油いの省透の約論

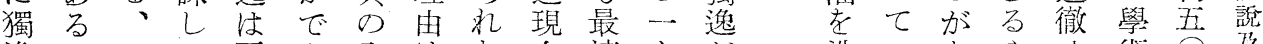

逸七て再あ全は在適とが

の・代軍つ部他第ののし斯

戰上用備てでの至財教での

時亏然文、渚向政の代如

對了料併幸索國世度で用交

策總工行にくを界びは燃石

は統業し \&主同動經な料油

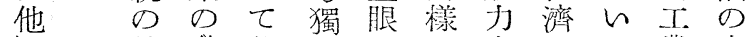

國統發其逸點江會狀加業自

の御達の注は國議態らを給

助力最石國芜飞占で選自

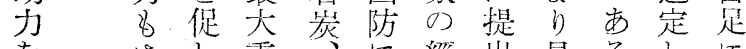

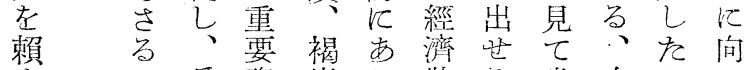

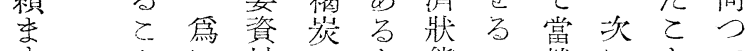

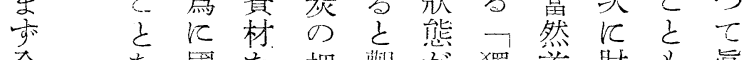

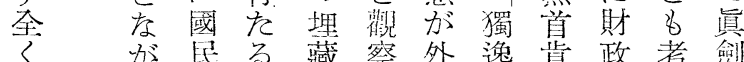

自 ら㾁液豐し貨にし上へな

力獨高體富得の於得國ら方

に逸價燃なる國け方際礼努

依國孛料る、外方貸る方

昆尚の故之流不子借がを

七唹自自之出炭所の之拂

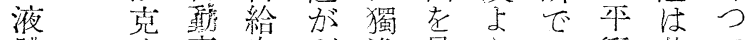

體々車自利逸最り市衝其て

燃國然足用最少自多を尚

料家料反近限動、得理る

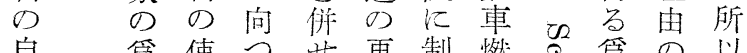

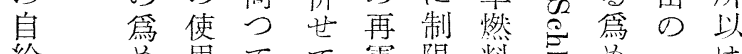

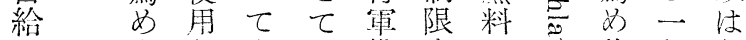

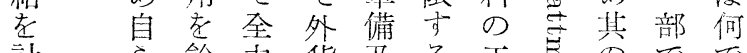

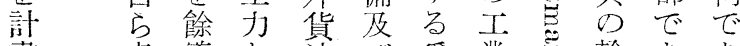

畫處儀を流び爲業輸ああ

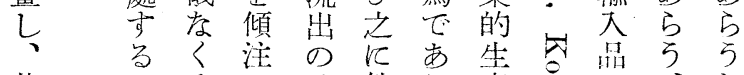

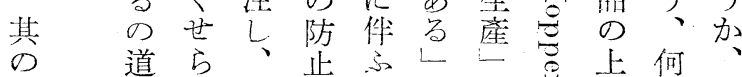

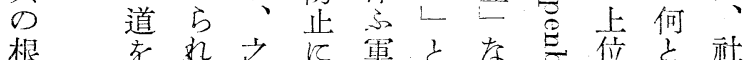

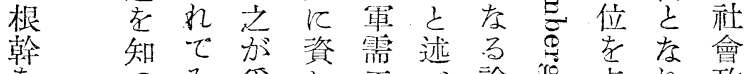

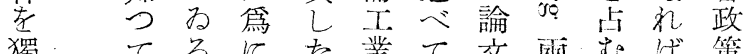

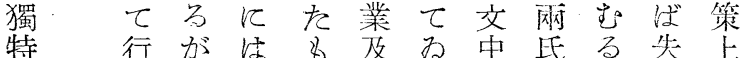

の動倘輸のずるには石業失

學世國大亡産、马昨油救業

問る家石考業然現年の濟者

とは國油へ汇在ワ自にを

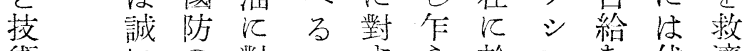

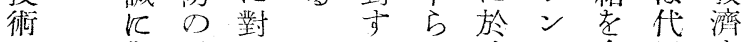

飞敬䈆し る此け下企用す

置服めて、態のるン圖燃る

き文高蔗理本に方料篇

值考弯由於る王の

造工あやせ 術

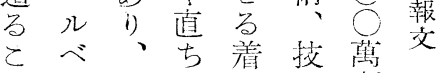

之河其飞䓳術噸

江のの之老主

成流重老以努其洲

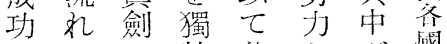

乙上等特其上召國

危褐当の分をり於

㷋態技着以り汁

獨の度術手てンる

逸露とを方せ約液

は天努以べば三體

あ掘少て 必 $\bigcirc$ 料

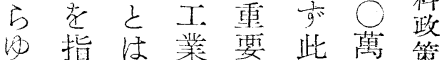

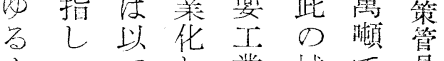

8 一兀業域で見

の西世、のに㐫

をの界炏種到る

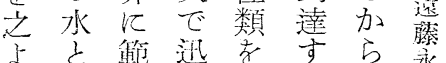

i) 石倠速選当

創炭示飞定で网郘

造 L 其 ᄂ 年

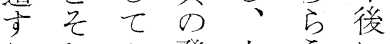

名し为發之与に

のてる垱沅於

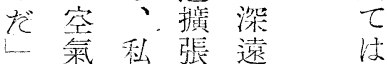

と学索劣

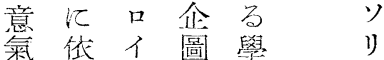

軒りナし理ン

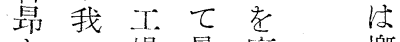

々 場最應概

乙索初用权

$\begin{array}{lllll}\tau & \text { 見 } & \text { の } \\ \text { 語 } & \text { 自目 } & \text { 給 }\end{array}$

モ L 的先自

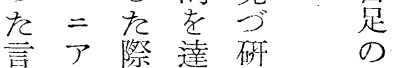

葉老案成究域

は人两守室比五

師造の后達四

方技狀於吉

今质態元学

日今架度萦誠老名

獨や留留處营

逸我去穓理見

態はの况、 


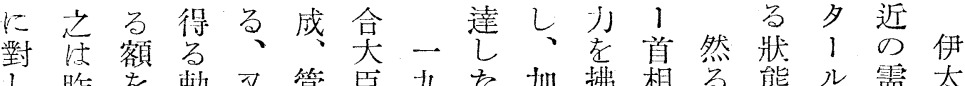

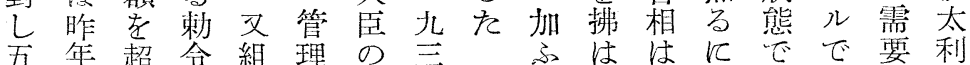

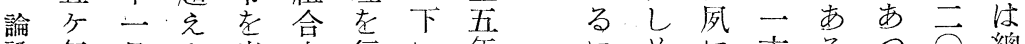

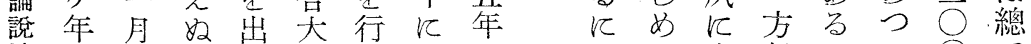

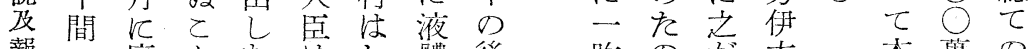

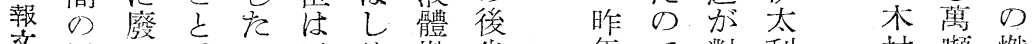

交通止、五め然牛年で對利材澒燃

行さガ又门料期伊策は は料

歐稅れソ礦 ○平特に后名に現

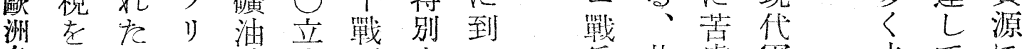

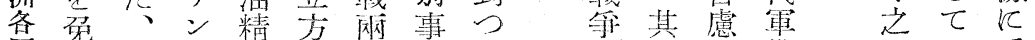

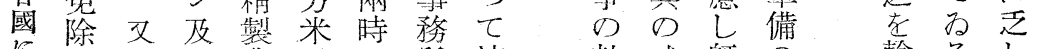

於し同び業以の所液勃成媓の

け、時其者上油存體發績に整

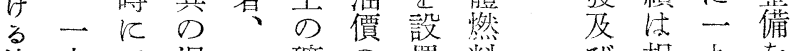

液方厂混一礦の置料

體自儿合般油汰しの

び相九烍

然動 ב然輸 故定て 自

料車 1 料入藏權陸給

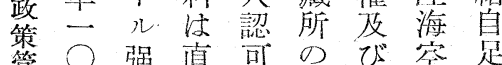

管 喜强直可接者所 小赛走

以混滔古有賣海

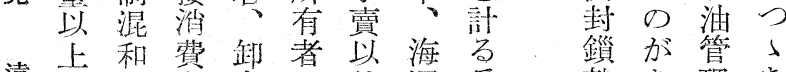

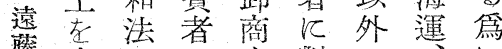

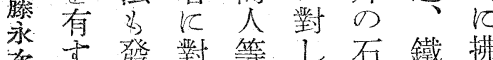

郎方令しは礦油道は

會さて單油商等 れ

䀦机のに使業金た

等て

に. \% 販 來目監家才

的見六年

件る年く

ふ心經き撗

滥多石乞

就亦理方

中つ本つ

不た部て

油唯党文

裁油設爲

蹈需て必

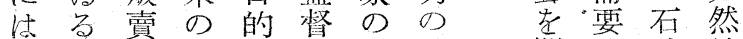

二 貝顧の權礦跡聞量油的

其得客如老油应

臺他る 他何與所幾

<度の K

飞子對飞年探液

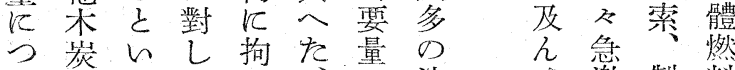

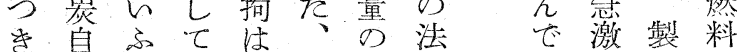

二動 がの ら其決令石に油の

喜車如

以のを販其費、直加業要

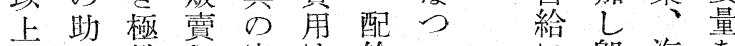

の成端し容は給て瓜海圭

割飞质得量組現對 5 外增

合關るての合輸は は最資加

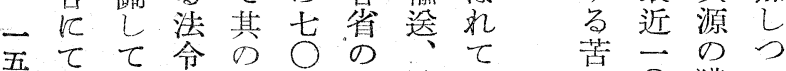

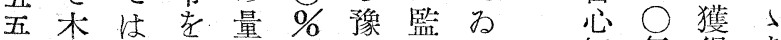

炭伊出庄以算梘る。努年得あ

自國 $L$ 前上卡电

動 製て 年の 計義 師

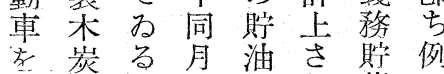

購自、学风藏心

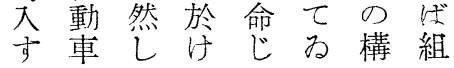

斿間等

其严

至ら倍ら

頂にゆ ソ

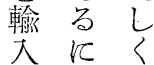

乙對 的

1 生 5

あ 産 石

当、僅 炭

又心 埋

ル「量

三僅

儿禹
顿

注四

芸過

のな億

廢々噸

糖、之

賞又稚

加世

ら用 ら

製 燃 れ

造 料 現

乙 資 在

て 源 需

y 上要

がて大

其の 部

の木分

生材快

產量㷊

年 林 輸

四面大

$\begin{array}{ll}\text { で } & \text { 實 } \\ \text { あ } & \text { 行 } \\ \text { る } & \text { を }\end{array}$

行

芜

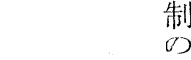

制

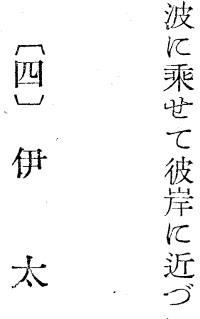

利少

n

る

c5

あ

$\tau$

不

油

$\frac{y}{\text { 有 }}$

3

比

脅

威

與

有

ぜ

3

國

は

光

與

五仗仰

萬五ざ。

亲 五。

飞○石

$\hat{\tau}$

わ

㛠葛 油

3

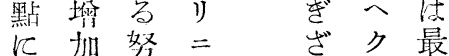


月二华二十和昭

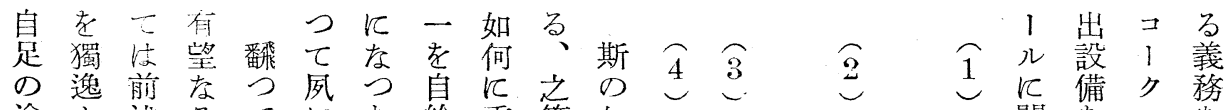

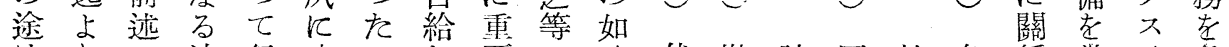
はりの油伊之涪要のく代燃計國於各係常及負論 な矆如田太が㐫得な法一用料畫產け種あにびは梳

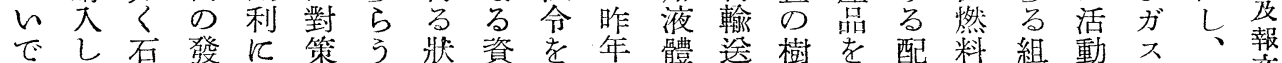

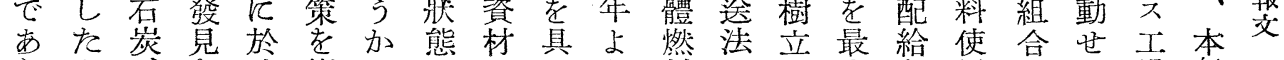

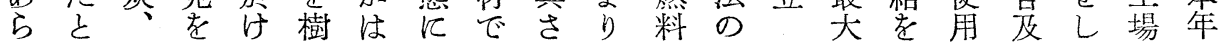
うの木期る立想止㐫に昨の改限顧のびむ並一歐 事材待液實像玉る見年使正度慮爲學可に月洲

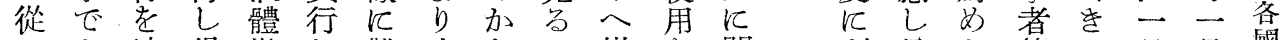
亦缺得燃し難大をと脚を關利且亦等と日旦或

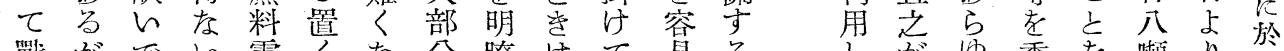
戰がでん需くな分瞭はて易るる名活委を吨り於

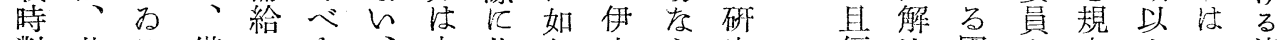

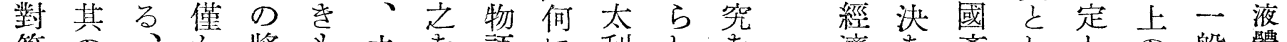

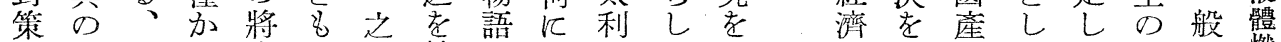
子原最に來のは輸つ伊の方行封圖原次疋褐交燃

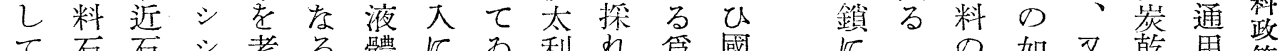

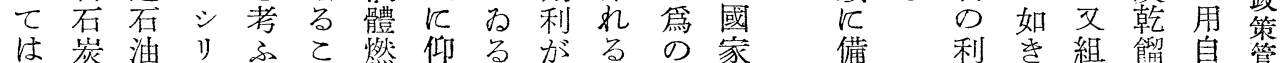

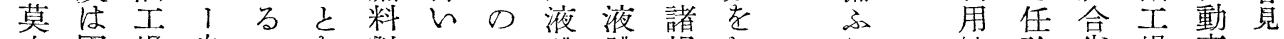
大國場島にを對でで體體規し、るる性務省場車

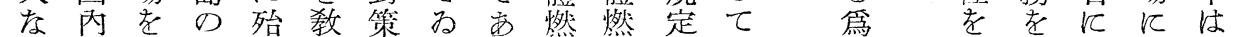

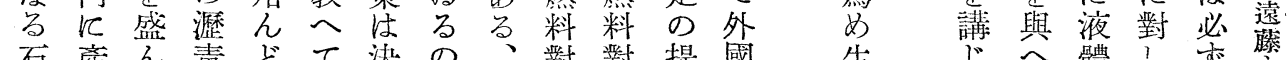

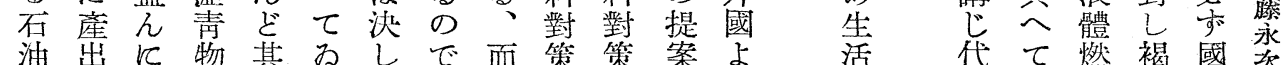

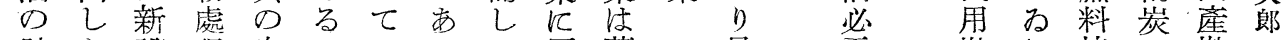
眝质設理自の一つて周箘最需然る協一然

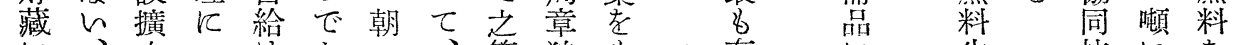

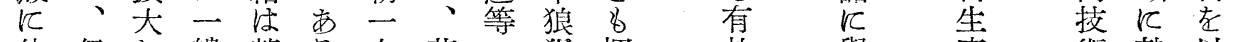
依伊乙緀望々夕若の狽㨔效與產術就以

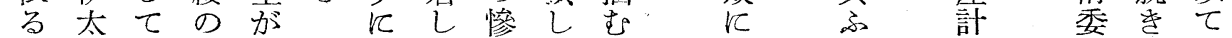

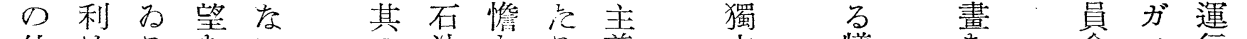

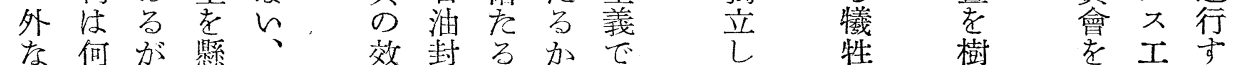

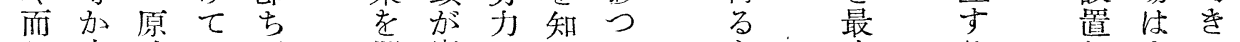

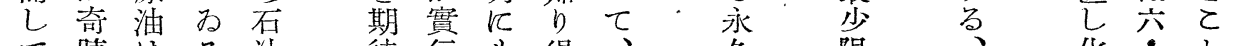

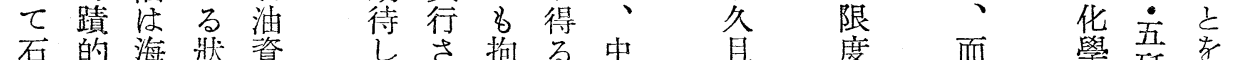

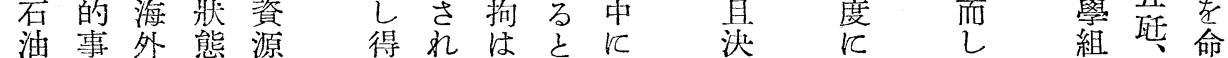

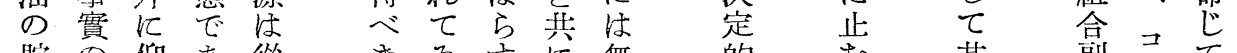
實 の仰 あ 從 藏發ぐつ來 生 の $\tau$ の は乙外、非 自古学常 限 限 又 代 努 度り石用力 が液 炭 燃に あ 體 液 料 8 る 燃化凟拘 の料の源は 息特と占 きわ专汇無的 当現謀 の ら 在 現 でば晌代 \& な伊石軍見 之太油備 ら 一朝需和る 有如量它き 事何 の 液 8 のな數體の 日妓燃す を狀分料 ら 思給許し杰慮態のがあ

る

如範

直韋

の

研

r

行

移 移 可 諸 


\section{號 三十七百第}

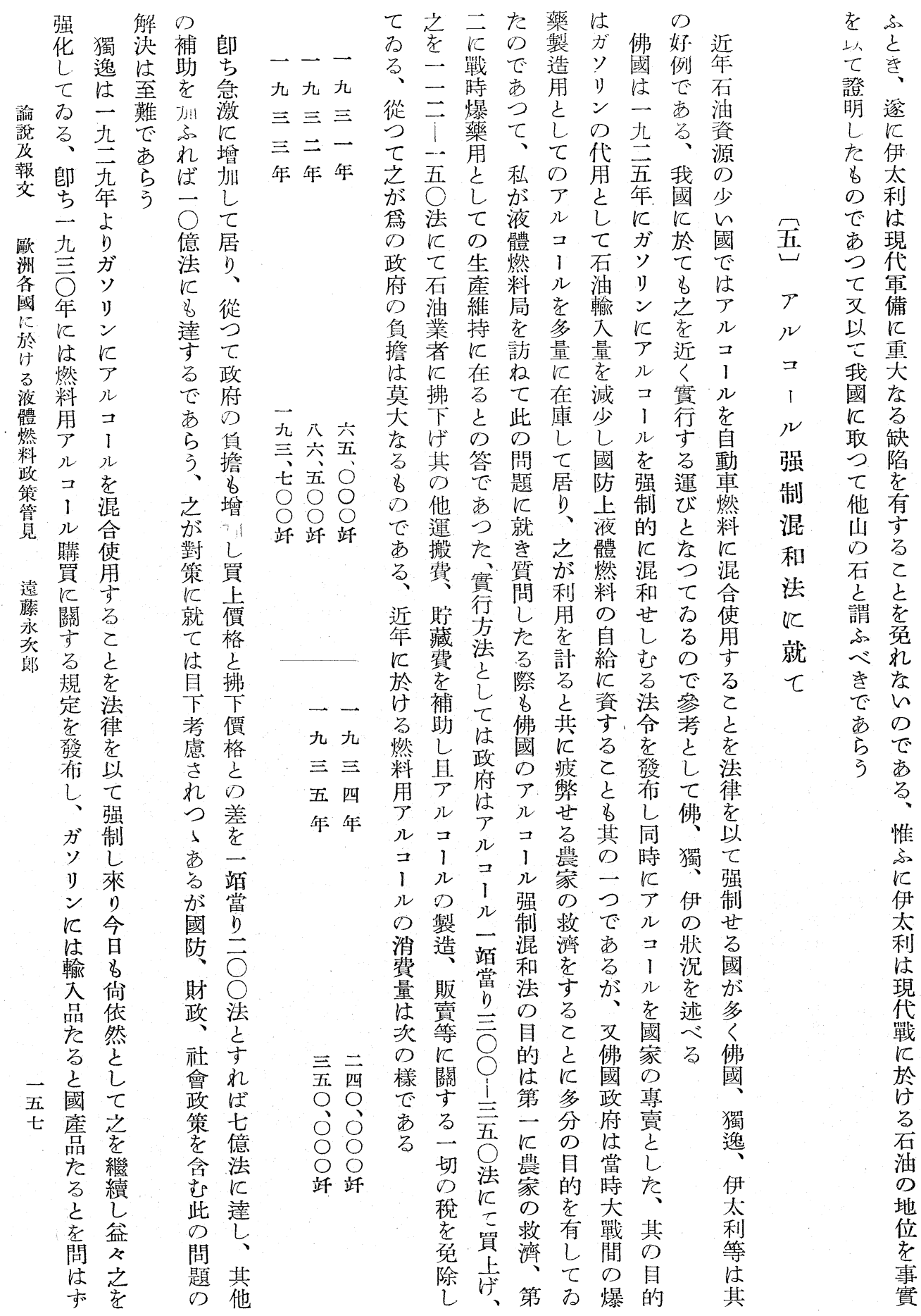


日二年二十和昭

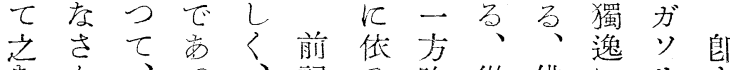

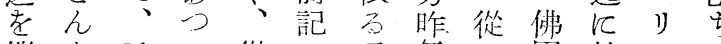
繼と又て從のア年つ國於ンア九九九

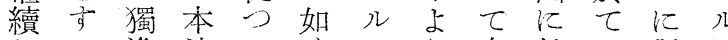
し 3 魀法てく

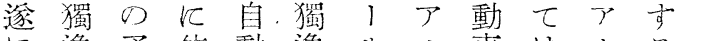

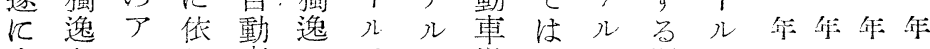
木とルれ車にはコ燃此コ混生 材しコ柋燃於澱了料》1 合産 糖て 1 食料け粉 ルの價ル割量 化年 $几$ 橿渻るにに價格原合に 法一强間費乃低メ格の料多對

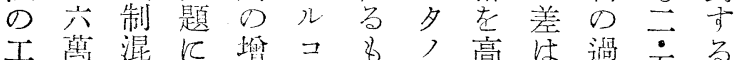
業

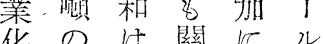
化のは闃にル〉ル自庫は\%料 飞了佛係俳生半を動の焉㫔 依儿國孛文產分混車負鈴—之 门コのくア量で合の㨜薯

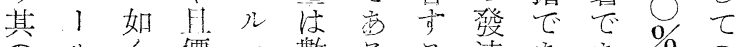

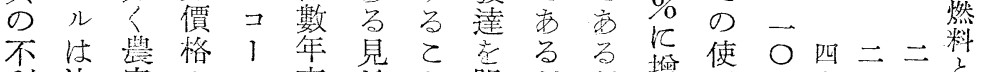
利沃家の儿來 をしの低使大 克て 救下角な

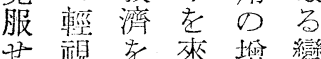
そ視索來增變 之 得眼 正量 弶 乙存と应索 $\tau$ 光 み\&て石に恐 るのみ 三 求ら ので孝鳥めく であんでる辰 西つ乙畐必產 るて 占名要 物 强推之生り 制定師じの 法苦布了 江來獨只儿 件る逸木コ 子の が材 I 熦で本糖儿 種京法化生 不多尔法產 利近老最 老注炽大 \& 不 顧油でにに みのみは達 梠自名好 ᄂ 斷給所適て 乎自以のわ 杗足范方る
害獨方妿用 依宗逸文 乙 合

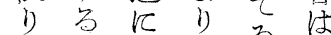
一乙於可 竨子攵了当九

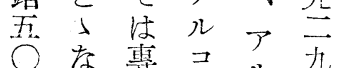
馬る簤当ル年 克の扁ルコに のでの-1 於 吕拂立强元 儿㤎下市强杂 1 歨格產㳊弱 ルの若和で が爲生应就历 四离約就 七自賈五常た 五重其へ等 馬㑭二問—

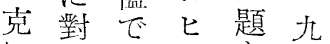
に市で焉 低鬲鬲吾 下課て ソ る 年 た考深方其は 更除費價價五 にし者の格\% 木ての約でに 材る負二あ蕾

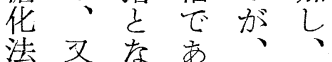
糖る擔倍る加
でせで其 西し要の $つ$ る 重 て其架量 昨 基昨出院 年三年 \% 及 十は七に坏 月 燃月相 一料水當 日用到李歐

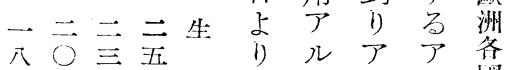
二六○分實コルル或 00000 施 1 ב 0000 巳 $00 \bigcirc \bigcirc$ 量 の的 七 三專を液 わ|賣ア る、四 $\begin{array}{ll}\text { 局 } \\ \%\end{array}$ 斯度於政 斯 及゙於 鏃

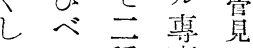

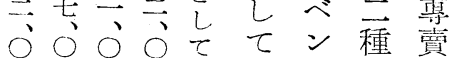
○○○○使然 ゙ョの局 料 1 混占遠 当儿合方藤 ル・燃䁲永 コ又料入郎 1夕をし 儿, 指て は1定混 獨儿L合 逸混、京 化合其方 於物 の乙 $\tau の-\varepsilon$ 近年㦓美 著主料務

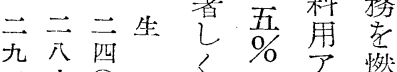
立六 ○穴斑其上 $上$ 製

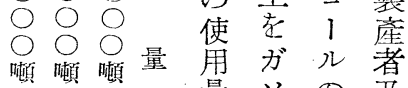
量りの文 蕾ン一輸五 加に\%大分 六五至料势混考普

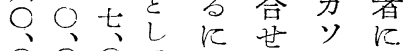
$\circ 9 \bigcirc$ 至 $L$ 負 ○○○使つむ熄 噸噸噸量たるにし 混 た 


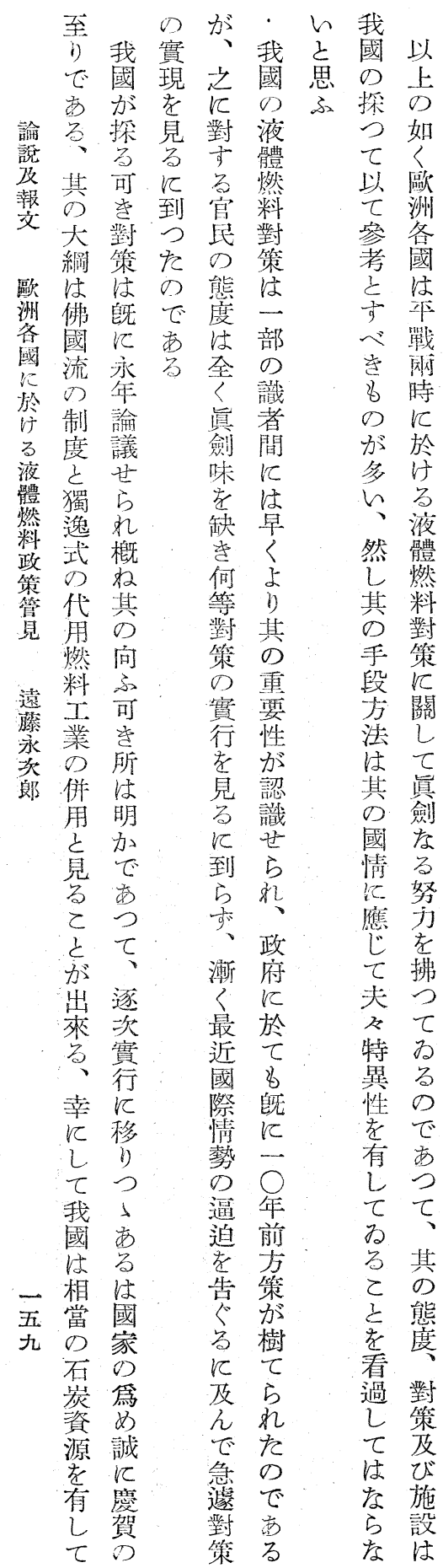

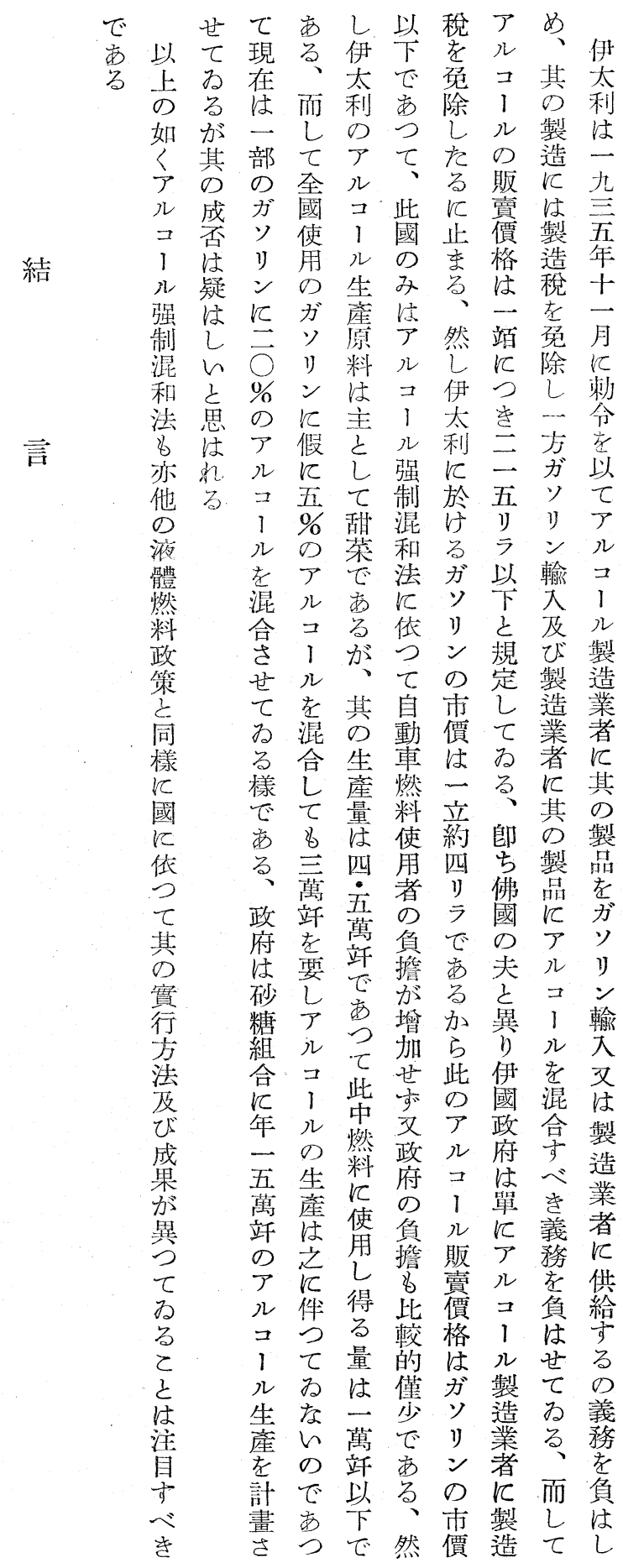

のるは而利あ除、の利 如が—しのつしル製は

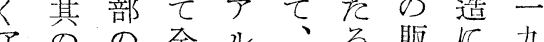
ル成ガ國コ此に賣は引 コ否ソ使、國止價製五 儿疑ンの生文名秷十

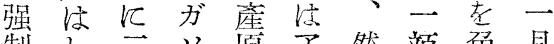
混 $\vec{\bigcirc}$ リ料儿然に除江 和亡 \%ンはコ伊つし赖 法思のに主1太太き …分

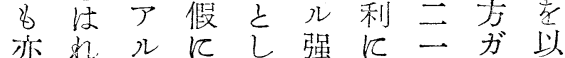
他る ב五て 制於五ソて の I \% 甜混けリリア 液 ルの㭉和るラン゙ 體老アで法ガ 以輸コ

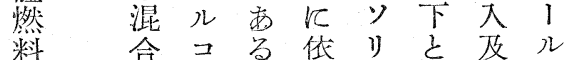
政さ、がつン規び製 策导儿其自市芫製造 同わ混の動價て 業者 樣る合生車はる者に に栐し產然一正に其 國てて 量料立其の 飞㐫名应使約郎の製 与蕾主者り佛品劣

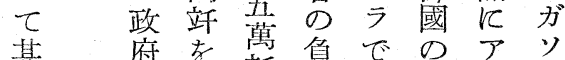

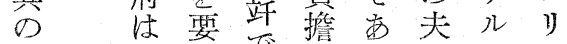

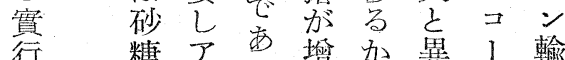

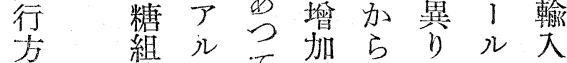
法合 コて此伊を 又 及、1觜市口國混汇 び年ル㶴 又 成五の然政ル府す去 が蕉產使の、單き羓

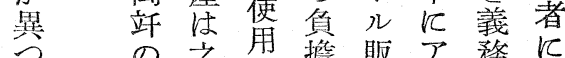

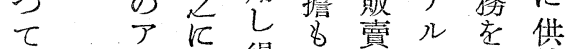
わ儿件得此價コ負給

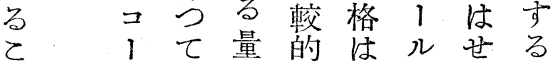
之学山僅ガ製て

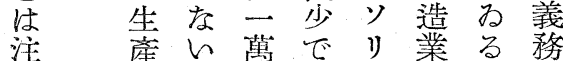
自老の站变ン者而急 心畫㐫午、市製しは きさつで然價造てし 


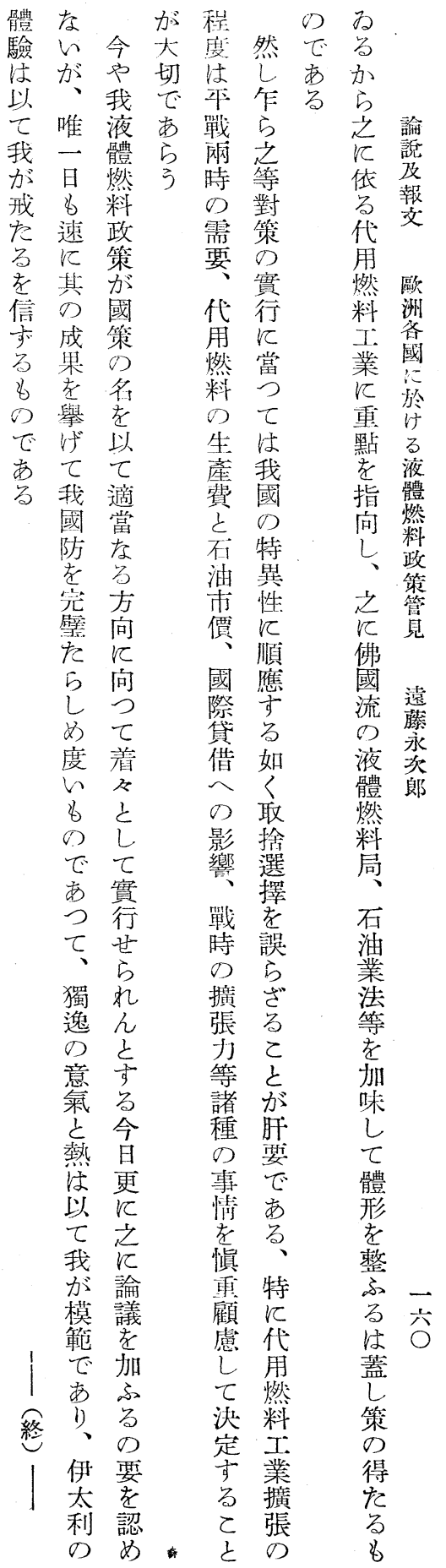

